\title{
RISK EXPOSURE ASSESSMENT OF SOME PESTICIDE RESIDUES DETECTED IN FRUIT AND VEGETABLES COLLECTED FROM DIFFERENT EGYPTIAN LOCAL MARKETS DURING 2008 \\ Khorshed, Mona A. \\ Central Laboratory of Residue analysis of Pesticides and Heavy Metals in Food, Agricultural Research Centre, Ministry of Agric., Dokki, Egypt.
}

\section{ABSTRACT}

A total of 530 samples of different types of the fruits and vegetables collected from nine Egyptian local markets located in nine governorates throughout 2008. All samples were examined for residues of 80 pesticides. Overall, results showed that $84.5 \%$ of the samples had no detectable pesticide residues, however, $15.5 \%$ contained detectable residues, of which $4.5 \%$ contained residues that exceeded maximum residue limits (MRLs). Apricot, banana, green celery, lettuce, samples were free from pesticide residues. The fruits samples recorded the highest contamination percentage without exceeding of the levels of MRL' (i.e. 20.8\%), followed by vegetables (i.e.8.7\%), and the leafy vegetables had the lowest percentage (i.e. $6.3 \%$ ). Also, data showed that the leafy vegetables recorded the highest violation \% (i.e. $7.2 \%$ ), followed by fruits (i.e. $4.2 \%$ ), and vegetables (i.e. $3.7 \%$ ). The violated samples were guava, strawberry, orange, carrot, cauliflower, cucumber, eggplant, G. beans, G. peas, pepper, potatoes, tomatoes, watercress, G. coriander, and G. parsley. The violated compounds were cypermethrin, chlorpyrifos, diazinon, fenhexamide, profenofos, fenhaxamid, ethion, and chlorfenapyr. The highest frequently detected pesticide was profenofos, followed by lambada-cyhalothrin, fenhexamid cypermethrin , ethion, chlorpyrifos, fenpropathrin , diazinon and imiazalil, carbendazin, dimethoate, and procymidone. However, the lowest frequently detected pesticides, which detected only one time, were boscalid, chlorfenapyr, flusilazole, iprodione, metalaxyl, pirimiphos, and pyraclostrobin. The results showed that $2.08 \%$ of all samples analyzed, contained residues of 9 pesticides, $1.13 \%$ contained residues of 8 pesticides, $0.94 \%$ contained residues of 6 pesticides, $2.26 \%$ contained residues of 5 pesticides, $0.38 \%$ contained residues of 4 pesticides, $3.21 \%$ contained residues of 3 pesticides, $3.4 \%$ contained residues of 2 pesticides, and $2.08 \%$ contained residues of 1 pesticide. The dietary exposures of the most frequently detected pesticides were theoretically calculated to evaluate the risk for Egyptian consumer. As shown by the results, the intake of pesticide residues does not exceed the ADI in any case. It is found to be below $10 \%$ of the ADI for all pesticides. The estimated exposure ranges from $0.00018 \%$ of the ADI for the malathion on each of molokia and spinach to $4.9 \%$ of the ADI for the ethion on tomato.

Keywords: Pesticide residues, fruits, vegetables, Dietary exposure.

\section{INTRODUCTION}

Pesticides are chemicals that are utilized by farmers to help them to produce their crops. Pesticides used in agriculture include insecticides, fungicides and herbicides. In vegetable and fruit production, insecticides are used to control pests and fungicides to control diseases. They are directly applied to the crops and some may still be present as residues in the vegetables and fruits after their harvests. It is true that insecticides and 


\section{Khorshed, Mona A.}

fungicides are toxic substances, but when used properly they constitute an important input in vegetable and fruit production in order to produce economically marketable products. On the one hand people are encouraged to consume more vegetables and fruits, these being a good source of vitamins and fiber and also beneficial to their health - and on the other hand, the mass media have rightly created an awareness about, but wrongly magnified the environmental and health problems and the risk involved in the use of chemicals, especially pesticides, in agriculture. Consequently, this has created a certain apprehension and fear in the public as to the presence of pesticide residues in their daily food. The public is confused and alarmed about food safety.

Pesticide residues in food have historically lagged far behind many comparable hazards as a cause for public health concern and action (Correia et al.., 2000; Eskenazi et al.., 2008). Pesticide residue contaminating food is the problem focused worldwide because of its direct implications on human health and international trade (Sanborn et al.., 2004). Reliable residue analysis data resulting from monitoring programs in foods, even if limited, may be of great value indicating the possible risks of pesticide exposure on human health and on international trade (DAF and FSAl, 2006).

Consumer protection is very highly considered by governments and authorities responsible for pesticides registration and use in each country and by the international organizations. Pesticide residue monitoring data in food serve in evaluating and clarifying the situation of potential human risk and trade problems. Such data could help decision makers in reviewing and reconsidering the registration and use of pesticides in the country. The aim of this study was to investigate a monitoring program for use of pesticide residue data in assessment of the possible risks that might affect human health and international trade.

\section{MATERIALS AND METHODS}

\section{Sampling:}

A total of 530 samples of different types of the fruits and vegetables collected from nine Egyptian local markets located in nine governorates (AI Obour, Great Cairo, Fayoum, Gharbiya, , Giza, Minufiya, Ismalia, Sharkiya, and Qalyubiya ) throughout 2008 . For residue analysis, $2 \mathrm{~kg}$ of each commodity was prepared according to Codex guidelines. The generally recommended method of sampling was used to obtain a representative part of the material to be analyzed. Samples were analyzed immediately upon their arrival at the laboratory, or they were stored at $0-5^{\circ} \mathrm{C}$ for 4 days before analysis. Samples were analyzed for 80 pesticides, which included organophosphorus, organonitrogen, and organochlorine compounds, and certain pyrethroids.

\section{Chemicals and reagents:}

(a) Solvents.-Acetone, dichloromethane, n-heaxane, petroleum ether, acetonitrile and (Pestiscan Chromatography grade or similar quality) ethanol $95-96 \%$. 
(b) Chemicals Anhydrous sodium sulphate (Riedel-de haen) sodium chloride, sodium hydroxide, and Florisil 60-100 mesh (Merck).

Reference standard:

All pesticides reference materials were certified standard and were provided by Dr. Ehrenstorfer Gmbl, Gogginer str.78 D-8900 Augoburg. Germany, and by the FAO (Food Agriculture Organization of the United Nations, Rome, Italy) and were prepared in $n$-hexane/acetone mixture.

A) Extraction and cleanup:

Multiresidue method for pesticides: In analyses according to the method described by Luke et al.. (1981), residues were extracted from representative homogenized portion of each non fatty food by blending with acetone or water-acetone. The pesticides were transferred from the aqueous filtrate into the organic phase by shaking with petroleum ether and dichloromethane; after drying, the organic phase is concentrated just to dryness and then dissolved in injection solution for determination by gas chromatography (GCs). The method allows determination of the 80 pesticide residues listed in Table 2, which also shows the commodities, spiking levels, average recoveries, and coefficients of variation (CVs). The cleanup was carried out using a florisil column, Organic phase was concentrated just to dryness and dissolved in injection solution (hexane/acetone (9:1) for GC-EC detection. This method allows the determination of 80 pesticide residues. The names of analyzed pesticides and their limit of determination is illustrated in table 1.

The investigated pesticides and their limit of determinations in $\mathrm{mg} / \mathrm{kg}$ were as follows:

\section{B) Determinations:}

Mutiresidue of pesticides: Qualitative and quantitative determination of pesticide residues in food samples depends on the use of two different polarities of chromatography columns. Each GC instrument (NPD, ECD) has its capillary columns with different polarities and consequently two detectors. The injection standard technique was followed for the quantitative determination. Aldrin was used for organochlorine and pyrethroid compounds; Ditalimphos for organophosphorous and organonitrogen compounds; as injection standard.

Quality Assurance procedures: All analytical methods and instructions were carefully validated as a part of the laboratory quality assurance system and were audited and accredited by the Center of Metrology and Accreditation Finnish Accreditation Service (FINAS) ISO/IEC Guide 25. The criteria of quality assurance were described by (Dogheim et al. . 2002). The recoveries were between $70-120 \%$ and CV less than 20\%. Low level fortification of all samples with the contaminants of interest has been carried out to ensure that the method performed satisfactory for the particular food examined. Analysis of duplicate of samples represents precision of analysis.

Apparatus and equipment:

- Gas chromatograph HP 5890 equipped with double electron capture detector (ECD) with two capillary column; injector $225^{\circ} \mathrm{C}$; detector $280^{\circ} \mathrm{C}$, operating conditions; nitrogen carrier gas $2.5 \mathrm{ml} / \mathrm{min} ; 65 \mathrm{ml} / \mathrm{min}$ (carrier + make up), column head pressure $82 \mathrm{~K} \mathrm{pa}$ 


\section{Khorshed, Mona A.}

- Gas Chromatograph, HP 6890 equipped with double nitrogen phosphorous detector (NPD) with two capillary columns; injector $225^{\circ} \mathrm{C}$ detector $280^{\circ} \mathrm{C}$. Operating conditions hydrogen $3.5 \pm 0.1 \mathrm{ml} / \mathrm{min}$; air 100 $110 \mathrm{ml} / \mathrm{min}$; nitrogen carriers gas $2.5 \mathrm{ml} / \mathrm{min}$ for both GC's. The specification of chromatography columns are as follows:

1. PAS-5 ECD tested ultra 2 silicon, $25 \mathrm{~m} \times 0.32 \mathrm{ml}$. Film thickness $0.52 \mu \mathrm{m}$.

2. PAS $-1701 \mathrm{ECD}$ tested 1701 silicon, $25 \mathrm{~m} \times 0.32 \mathrm{~mm}$ film thickness $0.25 \mu \mathrm{m}$. Temperature programs of both $\mathrm{GC}$ instruments were as follows; Initial temp $90^{\circ} \mathrm{C}$ for $2 \mathrm{~min}$; ramp (1) $20{ }^{\circ} \mathrm{C} / \mathrm{min}$ (to $150{ }^{\circ} \mathrm{C}$ ) ramp (2) $6{ }^{\circ} \mathrm{C}$ /min) to $270{ }^{\circ} \mathrm{C}$ hold for $15 \mathrm{~min}$.

Table (1): The names of pesticides analyzed and their limit of determinations

\begin{tabular}{|l|l|l|l|l|l|}
\hline Pesticide & LOD & Pesticide & LOD & Pesticide & LOD \\
\hline Acephate & 0.01 & Alachlor & 0.02 & Atrazine & 0.10 \\
\hline Bendiocarb & 0.10 & Bromopropylate & 0.05 & Carbaryl & 0.50 \\
\hline Carbosulfan & 0.10 & Captan & 0.10 & Chlorothalonil & 0.02 \\
\hline Chlorpyrifos & 0.02 & Chorpyrifos-methyl & 0.05 & Chlordane-transe & 0.02 \\
\hline Chlordane-cis & 0.02 & Cyanophos & 0.05 & Cyfluthrin & 0.10 \\
\hline Cypermethrin & 0.10 & Lambadacyhalothrin & 0.10 & Chlorpropham & 0.50 \\
\hline DDD-p,p & 0.02 & DDE-p,p & 0.02 & DDT-o,p & 0.02 \\
\hline DDT-p,p & 0.02 & Deltamethrin & 0.20 & Diazinon & 0.05 \\
\hline Dichlofluanid & 0.05 & Dicofol & 0.02 & Dieldrin & 0.01 \\
\hline Dimethoate & 0.05 & Diniconazole & 0.02 & Edifenfos & 0.10 \\
\hline Endosulfan-alpha & 0.02 & Endosulfan-beta & 0.02 & Endosulfan sulphate & 0.02 \\
\hline Endrin & 0.10 & Ethion & 0.10 & Fenamiphos & 0.10 \\
\hline Fenitrothion & 0.02 & Fenpropathrin & 0.05 & Fenthion & 0.05 \\
\hline Fenvalerate & 0.01 & HCH-alpha & 0.01 & HCH-beta & 0.02 \\
\hline HCH-delta & 0.01 & HCH-gamma(lindane) & 0.02 & Heptachlor & 0.01 \\
\hline Heptachlor epoxide. & 0.01 & Hexachlorobenzene & 0.01 & Imazailil & 0.01 \\
\hline Iprodion & 0.50 & Malathion & 0.02 & Metalaxyl & 0.20 \\
\hline Metamidiphos & 0.05 & Metrtibuzin & 0.10 & Monocrotophos & 0.05 \\
\hline Omethoate & 0.05 & Oxidiazone & 0.10 & Parathion & 0.05 \\
\hline Parathion-methyl & 0.05 & Pendimethalin & 0.10 & Permethrin & 0.10 \\
\hline Phenthoate & 0.10 & Phosalone & 0.05 & Phosphamidone & 0.10 \\
\hline Pirimicarb & 0.05 & Pirimiphos-ethyl & 0.02 & Pirimiphos-me & 0.05 \\
\hline Procymidone & 0.05 & Profenophos & 0.02 & Promcarb & 0.10 \\
\hline Propiconazole & 0.10 & Prothiofos & 0.02 & Pyrazophos & 0.02 \\
\hline Terbuconazole & 0.10 & Tetradifon & 0.03 & Tolcophos-me & 0.02 \\
\hline Triadmefon & 0.05 & Triadimenol & 0.10 & Triazophos & 0.02 \\
\hline Trifluraline & 0.01 & Vinclozolin & 0.01 & & \\
\hline
\end{tabular}

\section{RESULTS AND DISCUSSION}

Pesticide residues are substances that remain in or on air, water, soil, or food following its use. Even food grown without direct pesticide use can still contain residues due to spray drift from nearby farms, long range air transport, or existing groundwater or soil contamination.( Magkos F et al. 2003).

A total of 530 samples of different types of fruits and vegetables were examined for 80 pesticide residues. Fourteen types of vegetable crops were 
analyzed (i.e. cabbage, carrot, cauliflower, cucumber, eggplants, g. beans, g. peas, lettuce, pepper, potato, Squash and tomato), ten types of fruits ( apple, apricot, banana, grape, cantaloupe, guava, strawberry, orange, peach, and pomegranate) and eight types of leafy vegetables( watercress, spinach, molokhia, g. leaf, g. celery, g. coriander, and g. parsley). All samples were examined for residues of 80 pesticides listed in Table (1). The detected pesticides, minimum, maximum, mean detected levels, and the numbers and the percentages of violative samples are shown in Table (2). The MRLs of Codex Alimentarius were used for comparison when those limits were available. In the absence of Codex MRLs, European limits were used.

Overall, $84.5 \%$ of the samples had no detectable pesticide residues, however, $15.5 \%$ contained detectable residues, of which $4.5 \%$ contained residues that exceeded maximum residue limits (MRLs). Apricot, banana, $g$. celery, lettuce, samples were free from pesticide residues. Fig (1) showed that the percentage of the free samples in the vegetables was higher than that in the leafy vegetables. However, the lowest percentage was in the fruits. Results showed that fruits recorded the highest contamination percentage without exceeding of the levels of MRL' (i.e. 20.8\%), followed by vegetables (i.e.8.7\%), and the leafy vegetables had the lowest percentage (i.e. 6.3\%). Also, results showed that the leafy vegetables recorded the highest violation $\%$ (i.e. $7.2 \%$ ), followed by fruits (i.e. $4.2 \%$ ), and vegetables (i.e. $3.7 \%$ ).

Fruits

A total of 120 fruit samples were subjected to residues analysis. Results showed that $75 \%$ of all samples analyzed were free from any residues. However, only $25 \%$ of samples were contaminated with detectable amount of pesticide residues. Only 5 samples of this contaminated samples contained levels of residues exceeded the established MRL's. All apricot and banana samples were free from any residues.

Figure (1), showed that $75 \%$ of all fruit samples analyzed were free from any residues. However, $20.8 \%$ of analyzed samples contained detectable residues of pesticides, but without exceeding of MRL's established for each pesticide, while $4.2 \%$ of fruit samples analyzed contained levels of residues exceeded the MRL's for each detected pesticide. The violated samples were guava, strawberry, and orange. The violated compounds were cypermethrin, chlorpyrifos, diazinon, fenhexamide, and profenofos.

Vegetables:

A total of 299 samples of different types of vegetables were subjected to analysis. Data showed that $87.6 \%$ of all samples were free from any pesticide residues. However, $8.7 \%$ of samples contained detectable levels of pesticides residues, but without exceeding of MRL established for established for each pesticide. Results showed that $3.7 \%$ of samples contained with residues at levels above their established MRL's. 
Khorshed, Mona A.

2 
J. Plant Prot. and Path., Mansoura Univ., Vol. 3 (2), February, 2012 
Khorshed, Mona A.

146 
J. Plant Prot. and Path., Mansoura Univ., Vol. 3 (2), February, 2012 
Khorshed, Mona A. 
J. Plant Prot. and Path., Mansoura Univ., Vol. 3 (2), February, 2012 
Khorshed, Mona A.

150 


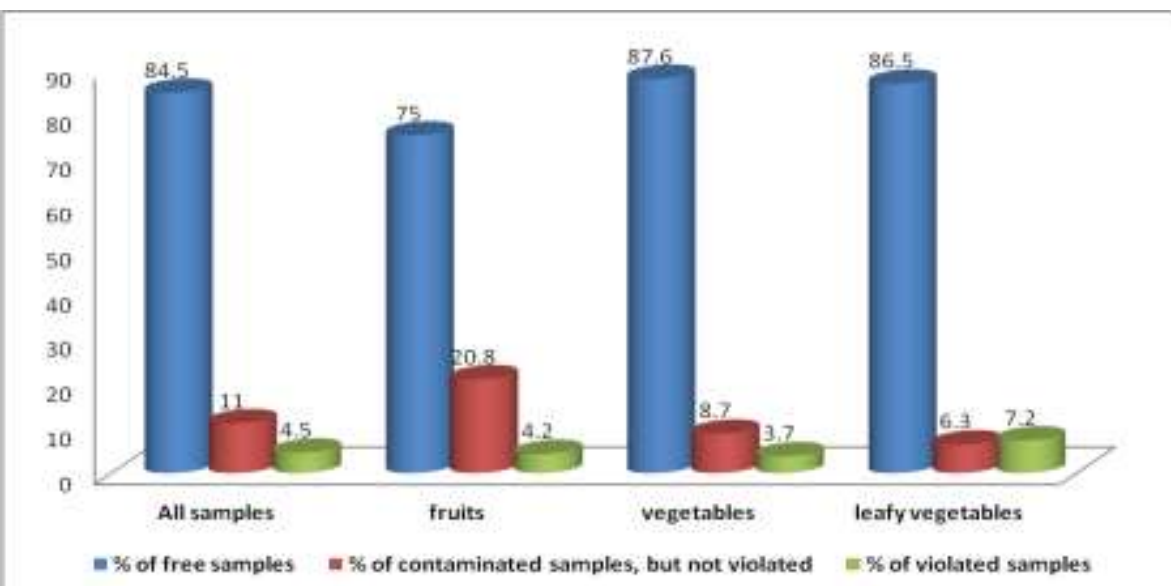

Fig. (1): The contamination and the violation percentages in the different types of vegetables and fruits collected from Egyptian local markets during 2008:

The violated samples were carrot, cauliflower, cucumber, eggplant, G. beans, G. peas, pepper, potatoes, and tomatoes.

The violated compounds were profenofos (i.e in 2 samples), fenhaxamid (i.e in 4 samples ), cypermethrin (i.e in 1 samples), ethion(i.e in 3 samples), and chlorfenapyr (i.e in 1 samples).

\section{Leafy vegetables:}

A total of 111 samples were subjected to analysis. The results demonstrated that $86.5 \%$ of all samples analyzed were free from any residues. However, only $6.3 \%$ of samples were contaminated with detectable residues, but without exceeding of limits of MRL's. Data showed that $7.2 \%$ of all samples analyzed contaminated with residue levels exceeded the established MRL's for each pesticide. The violated compounds were profenofos (i.e in 6 samples), chlorpyrifos, and the violated samples were watercress, G. coriander, and G. parsley.

Fruits recorded the highest contamination percentage, followed by vegetables and finally the leafy vegetables. In spite of the lowest contamination percentage of leafy vegetables, it had the highest violation \%. These differences would be expected because pesticides are applied directly to the edible commodity, and fruit is often treated close to the time of harvest to ensure that wholesome produce reaches the consumer. In addition, processing treatments such as washing, peeling, canning, or cooking that most foods receive before consumption are very important factors leading to a decrease in the levels of show that root vegetable samples had the lowest contamination rate, with none exceeding the MRLs (Dogheim et al., 2001).

Fig (2) showed the frequency numbers of the pesticide residues detected in the samples. 
Khorshed, Mona A.

Fig. (2): Frequency numbers of residues found overall concentration ranges in fruit and Vegetable samples collected from Egyptian local markets during 2008:

The highest frequently detected pesticide was profenofos which detected in 17 samples, followed by lambada-cyhalothrin which detected in 14 samples, fenhexamid (i.e. 12 samples), cypermethrin and ethion each detected in 9 samples, and the chlorpyrifos and fenpropathrin each detected in 7 samples, each of diazinon and imiazalil detected three times, both of carbendazin, dimethoate, and procymidone detected two times. However, the lowest frequently detected pesticides, which detected only one time were boscalid, chlorfenapyr, flusilazole, iprodione, metalaxyl, pirimiphos, and pyraclostrobin.

The percentage of samples contaminated with residues of $\square 10$ pesticides are listed in Fig (3), results showed that $2.08 \%$ of all samples were analyzed, contained residues of 9 pesticides, $1.13 \%$ contained residues of 8 pesticides, $0.94 \%$ contained residues of 6 pesticides, $2.26 \%$ contained residues of 5 pesticides, $0.38 \%$ contained residues of 4 pesticides, $3.21 \%$ contained residues of 3 pesticides, $3.4 \%$ contained residues of 2 pesticides, and $2.08 \%$ contained residues of 1 pesticides. Multiple residues are expected on fruits and vegetables because various classes of pesticides must be alternated to prevent resistance from developing in pests. In addition to this reason for multiple residues justified by agricultural practices, other possible reasons for the occurrence of multiple residues are residues resulting from uptake via soil in cases where pesticides have high persistence in soil; contamination during storage; mixing of lots which were treated with different pesticides, either during the sampling or in the course of sorting the commodities; residues resulting from spray drift from neighboring plots or cross contamination in the processing of crops (e.g. by washing practices) (EFSA,2010) 


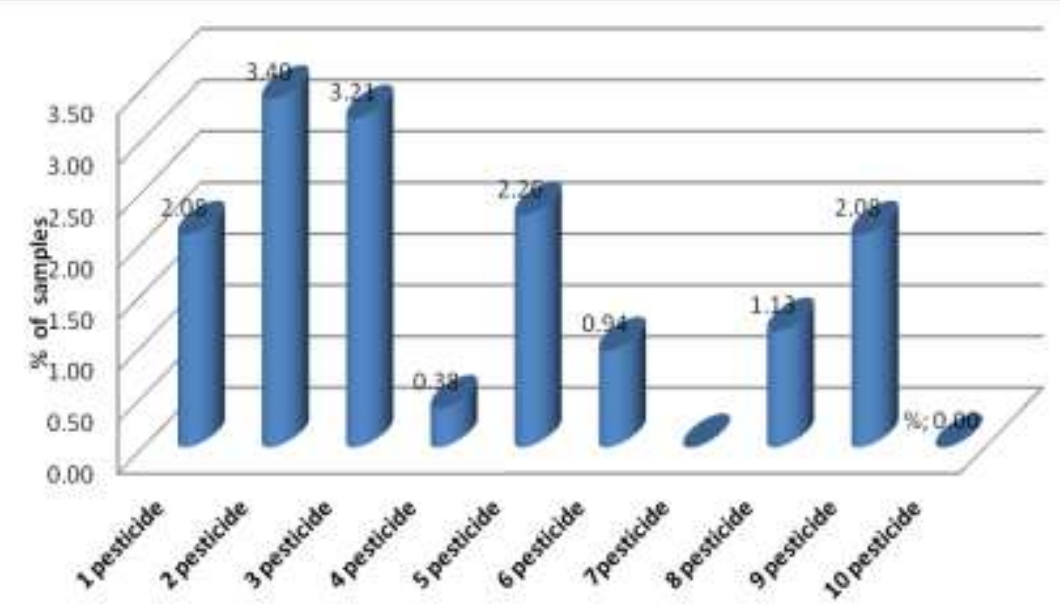

Fig. (3): The percentage of samples with residues of more than one pesticide

\section{Dietary exposure and dietary risk assessment:}

Dietary exposure assessment is defined by Codex Alimentarius as "the qualitative and/or quantitative evaluation of the likely intake of chemical agents via food as well as exposure from other sources, if relevant" (FAO 2006). Exposure is basically a function of the amount of consumed food and the concentration of the chemical (e.g. pesticide residue concentration) and can be expressed by the following equation:

Dietary exposure $=\underline{\Sigma(\text { residue concentration } \mathrm{x} \text { food consumption })}$

\section{Body weight}

In the chronic (long-term) risk assessment, the estimated dietary exposure is compared to the relevant toxicological reference values, i.e. the acceptable daily intake (ADI) which was derived after a full hazard characterization of the compound. The consumer is considered to be adequately protected if the estimated dietary intake of a pesticide residue does not exceed the ADI.

The estimation of the exposure to pesticide residues in the Egyptian population was performed, using the mean residue of the detected pesticides and food consumption data of each contaminated food obtained from GEMS food consumption (GEMS/Foods) (2006) data, C, in kg/day/ body weight, based on a $60 \mathrm{~kg}$ person (WHO, 1997). The calculated TADl's were compared with the acceptable daily intake for the compounds, ADI (Codex, 2010), and expressed as \% ADI.

$\% \mathrm{ADI}=(\mathrm{TMDI} / \mathrm{ADI}) \times 100$

The 13 pesticides, which were the most frequently detected in the samples, were chosen for the dietary intake assessment; the chronic risk assessment is performed for all commodities. The average pesticides residue levels were calculated by using residue data from the monitoring data. The results of the TMDI calculation are reported separately for each pesticide in an exposure 
Khorshed, Mona A.

assessment. If the ADI was not exceeded in any commodity, a chronic consumer risk can be excluded.

Table 3: Number of samples with residues of more than one pesticide

\begin{tabular}{|c|c|c|c|c|c|c|c|c|c|c|c|}
\hline Crops & 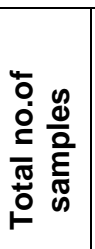 & 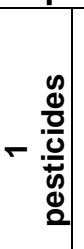 & 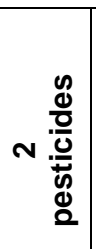 & $m \frac{\substack{d \\
\frac{0}{0}}}{\stackrel{d}{\underline{d}}}$ & $+\frac{\frac{g}{d}}{\frac{0}{0}}$ & 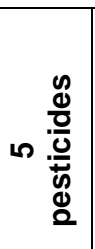 & $0 \stackrel{\frac{g}{0}}{\frac{0}{0}}$ & $\sim \frac{\mathscr{g}}{\frac{0}{0}}$ & $\begin{array}{l}\mathscr{d} \\
\frac{0}{0} \\
\frac{0}{0} \\
\frac{\hat{d}}{d} \\
\stackrel{0}{0} \\
\infty\end{array}$ & 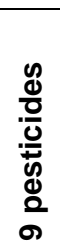 & 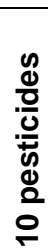 \\
\hline Apple & 4 & & & & 2 & & & & & & \\
\hline Apricot & 3 & & & & & & & & & & \\
\hline Banana & 28 & & & & & & & & & & \\
\hline Cantaloupe & 17 & & 1 & & & & & & & & \\
\hline Grape & 4 & & & 1 & & & & & & & \\
\hline Guava & 13 & & 7 & & & & & & & & \\
\hline Strawberry & 19 & & & & & & & & 6 & & \\
\hline Orange & 24 & & & & & & & & & 11 & \\
\hline Peach & 7 & & 1 & & & & & & & & \\
\hline Pomegranate & 1 & & 1 & & & & & & & & \\
\hline Cabbage & 23 & & 2 & & & & & & & & \\
\hline Carrot & 22 & 1 & & & & & & & & & \\
\hline Cauliflower & 22 & 1 & & & & & & & & & \\
\hline Cucumber & 22 & & & & & 7 & & & & & \\
\hline Eggplant & 37 & & & 4 & & & & & & & \\
\hline Green beans & 20 & & & 3 & & & & & & & \\
\hline Green peas & 25 & & & & & 5 & & & & & \\
\hline lettuce & 20 & & & & & & & & & & \\
\hline Molokai & 10 & 1 & & & & & & & & & \\
\hline Pepper & 25 & & & 4 & & & & & & & \\
\hline Potatoes & 24 & 2 & & & & & & & & & \\
\hline Squash & 24 & & 2 & & & & & & & & \\
\hline Tomatoes & 25 & & & & & & 5 & & & & \\
\hline Water cress & 23 & 3 & & & & & & & & & \\
\hline Spinach & 24 & 1 & & & & & & & & & \\
\hline Egyptian mallow & 15 & 1 & & & & & & & & & \\
\hline Grape leaf & 7 & 1 & & & & & & & & & \\
\hline Green celery & 2 & & & & & & & & & & \\
\hline Green coriander & 17 & & 4 & & & & & & & & \\
\hline Green parsley & 23 & & & 5 & & & & & & & \\
\hline Total no. & 530 & 11 & 18 & 17 & 2 & 12 & 5 & 0 & 6 & 11 & 0 \\
\hline
\end{tabular}

As shown by the results in Table (4), the intake of pesticide residues does not exceed the ADI in any case. The estimated exposure ranges from $0.00018 \%$ of the ADI for the malathion on each of molokia and spinach to $4.9 \%$ of the ADI for the ethion on tomato. 
J. Plant Prot. and Path., Mansoura Univ., Vol. 3 (2), February, 2012 
Khorshed, Mona A.

156 
Figure (5): Total intake of selected pesticides calculated in \% of the ADI

Fig (5), demonstrated that the total intake of ethion was higher than that of profenofos, followed by dimethoate, imazalil, fenhexamid, and diazinon. This is due to their wide range of using on fruits and vegetables to control a wide range of the diseases. While all of them still below $10 \%$ of the ADI for all pesticides.

Pesticides can have a cumulative "toxic loading" effect both in the immediate and long term, and each person accumulates and responds to chemicals in a way that is biochemically and biographically unique. From birth, we build up a chemical "body burden" that reflects a combination of childhood and workplace exposures, pesticide residues on food, chemicals in home and personal care products and the quality of air and water in our communities.

The process of dietary pesticide risk assessment has been presented and three major components of the process estimation of pesticide residue levels, estimation of food consumption patterns, and characterization of risk based on a comparison of exposure estimates with toxicological criteria have been identified. Each component of the process is subject to considerable uncertainty that may compromise the accuracy of the final risk assessment. In estimating pesticide residue levels, common practices range from highly theoretical models assuming that all residues are present at a predetermined level (typically at the tolerance level) to the use of market basket survey data obtained at the time the food is ready for consumption. 


\section{Khorshed, Mona A.}

Risk of adverse health effects is a function of pesticide toxicity and exposure. Exposure to a pesticide determines the dose and the pesticide's toxicity determines the potency of the dose. For pesticides that do not cause cancer, there is a dose below which there will be no effect. For pesticides that do not cause cancer, a no effect threshold has been determined for each pesticide, which is inversely related to its potency.

For pesticides that may cause cancer the probability that exposure will result in cancer is related to dose, the greater the exposure the greater the probability of cancer. In each case risk is directly related to exposure, as exposure determines dose. If exposure is low enough the risk of adverse health effects is nil.

Because the residual build up of a pesticide is so long-term, it's difficult to prove it's happening, but many Egyptian people prefer not to risk exposure to pesticides.

The Egyptian Organizations of Standardization should sets and revise the Egyptian maximum residue levels according risk exposure data and Egyptian food habit consumption, what it calls an "approved usage" level of a pesticide - essentially a safety limit on how much can make its way into the food chain. However, the approved usage level is set down for adults, potentially putting children at risk.

Currently, there is very limited data on Egyptian dietary pesticide exposure levels, and no data on the relative health risks and benefits of consuming organically- versus conventionally-grown food. Available data suggest that organic food contains fewer synthetic pesticide residues than conventional food, and eating an organic diet can result in lower exposures to some pesticides. However, given the current weight-of-evidence, it cannot be concluded based on its potential for reduction of exposure to pesticides that an organic diet provides greater health benefits than a conventional diet, although organically-grown food may provide other perceived benefits to consumers.

Egypt really need more research is needed to quantify Egyptian dietary risk exposure data and other sources of pesticide exposures among different segments of the Egyptian population, also potential health effects from lowlevel dietary pesticide exposures, and the relative risks and benefits of an organic versus conventional diet. In particular, there remain significant gaps in scientific knowledge with respect to differences in pesticide residue (synthetic and natural), microbial pathogen, mycotoxin, and natural toxin levels in organically-grown versus conventionally-grown food.

\section{REFERENCES}

Baker B, Benbrook C, Groth E, Benbrook K. Pesticide residues in conventional, IPM-grown and organic foods: Insights from three US data sets. Food Addit Contam. 2002; 19(5):427-46.

Bassil K, Vakil C, Sanborn M, Cole D, Kaur J, Kerr K. Cancer health effects of pesticides: Systematic review. Can. Fam. Physician. 2007; 53(10):1704-11. 
CODEX .2010. Codex alimentarius commission Pesticide residues in food and feed. Downloaded from http://www.codexalimentarius.net/pestres/data/pesticides/index.html

Codex Alimentarius Commission (1993) Joint FAO/WHO Food Standards Programme, Vol. 2, sec. 4, p. 391

Correia, M., Delerue-Matos, C. and Alves, A. (2000). Multiresidue methodology for pesticide screening in wines.Chromatography A 889: 59-67.

DAF (Department of Agriculture and Food's) under the terms of a service contract with FSAI (the Food Safety Authority of Ireland). 2006. Pesticide residues in food 2005. Pesticide control service, Back Weston Campus, young's cross, celbridge, co Kildare, Ireland.

Dogheim, S. M., Gadalla, S.A., Salama, E. Y., El-Marsafy, A. M. and Nabil, Y. M. (2002). Monitoring of pesticide residues in Egyptian fruits and vegetables during 1997.Food Additive and Contaminants 19(11): 10151027.

Dogheim, S.M., Gad Alla, S.A., \& El-Marsafy, A.M. (2001). Monitoring of Pesticide Residues in Egyptian Fruits and Vegetables During 1996. J. AOAC Int..vol. 84, No.(2) 519-531.

EFSA European Food Safety Authority, (2010) . Annual report the EFSA Scientific Network for Risk Assessment of GMOs; 8(6):1646

Eskenazi, B., Rosas, L. G., Marks, A. R., Bradman, A., Harley, K., Holland, N., Johnson, C., Fenster, L.and Barr, D. B. 2008. Pesticide toxicity and the developing brain. Basic and Clinical. Pharmacology and Toxicology 102 (2): 228-236.

(FAO) Food and Agriculture Organization of United Nations (2006).

Fenske R, Kedan G, Lu C, Fisker-Andersen J, Curl C. Assessment of organophosphorous pesticide exposures in the diets of preschool children in Washington State. Journal Expo. Anal. Environ. Epidemiol. 2002; 12(1):21-8.

Global Environment Monitoring System-Food Contamination Monitoring and Assessment Program (GEMS/Foods) (2006). Program of Food Safety and Food Aid, Geneva, Switzerland.

Luke, M.A., Froberg, J.E., Doose, G.M., \& Masumato, H.T. (1981), Improved multiresidue gas chromatographic determination of organophosphorous, organonitrogen, and organohalogen pesticides in produce, using flame photometric and electrolytic conductivity detecttors, J. Assoc. Off. Anal. Chem. 64, 1187-1195

Magkos F, Arvaniti F, Zampelas A.(2003) Putting the safety of organic food into perspective. Nutrition Research Reviews. 2003; 16:211-221.

Sanborn M, Kerr, K, Sanin L, Cole D, Bassil K, Vakil C (2004). Non-cancer health effects of pesticides: Systematic review and implications for family doctors. Can. Fam. Physician. 2007; 53(10):1712-1720.

World Health Organization (WHO), (1997). Guidelines for predicting dietary intake of pesticides residues. 
Khorshed, Mona A.

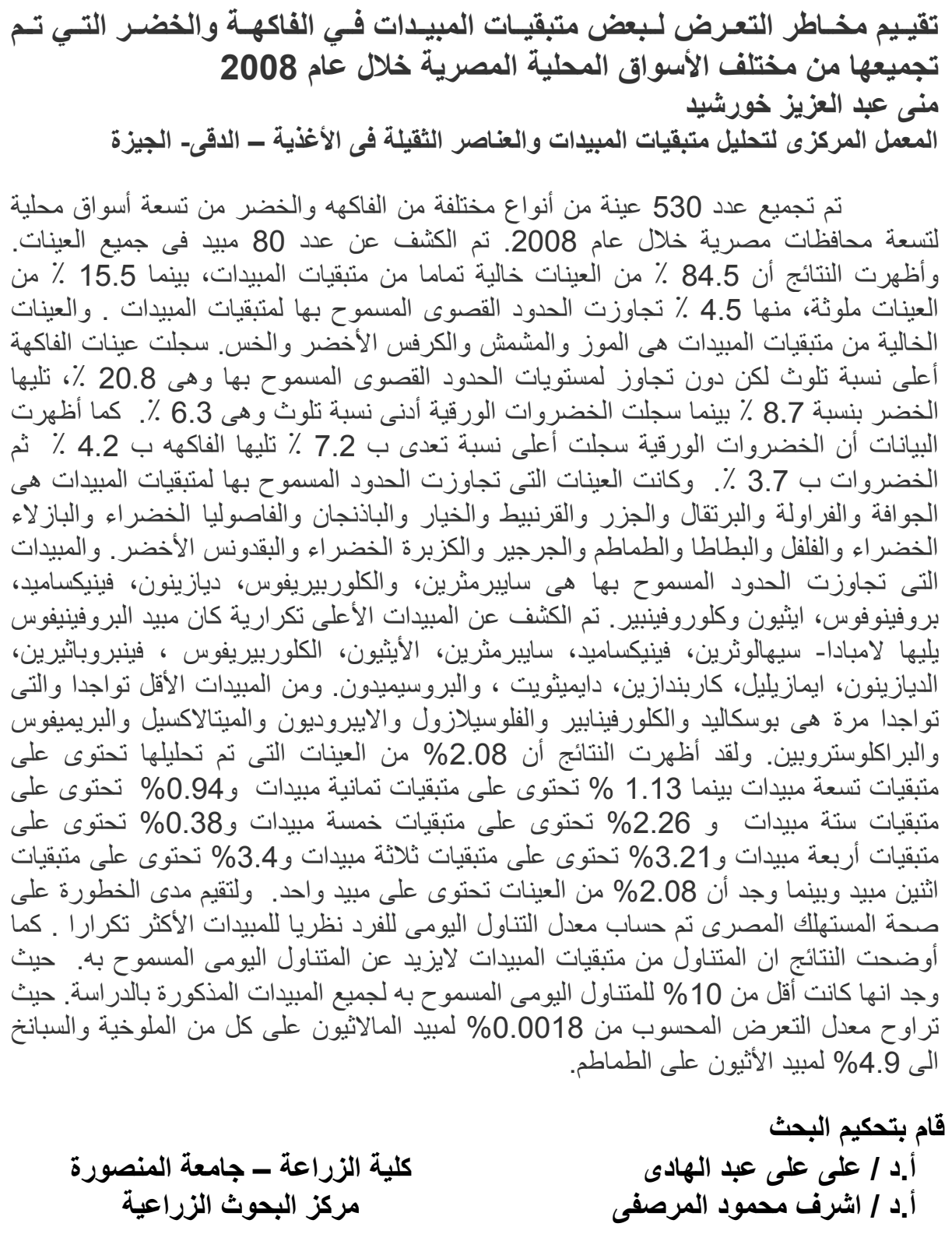


Table (2): The pesticides residues detected, minimum, maximum, mean, and the percentages of violative samples in the fruit and vegetables collected from different Egyptian local markets during 2008

\begin{tabular}{|c|c|c|c|c|c|c|c|c|c|c|c|}
\hline Commodity & $\begin{array}{c}\text { Total no. } \\
\text { of } \\
\text { analyzed } \\
\text { samples }\end{array}$ & $\begin{array}{l}\text { The detected } \\
\text { pesticide }\end{array}$ & $\begin{array}{l}\text { Contamina- } \\
\text { tion. number }\end{array}$ & $\begin{array}{c}\text { Contamination } \\
\text { percentage }\end{array}$ & frequency & minimum & maximum & mean & $\begin{array}{c}\text { Maximum } \\
\text { Residue } \\
\text { Limits } \\
\text { (MRL) }\end{array}$ & $\begin{array}{c}\text { Violation } \\
\text { No. }\end{array}$ & $\begin{array}{c}\text { Violation } \\
\%\end{array}$ \\
\hline \multirow{4}{*}{\begin{tabular}{|l} 
Fruits: \\
Apple
\end{tabular}} & \multirow{4}{*}{4} & Carbendazim & \multirow[t]{4}{*}{2} & \multirow{4}{*}{50} & 1 & 0.09 & 0.09 & 0.09 & 3 & - & - \\
\hline & & \multirow{3}{*}{\begin{tabular}{|l|} 
Cypermethrin \\
Fenpropathrin \\
Lambda- \\
Cyhalothrin \\
\end{tabular}} & & & 1 & 0.04 & 0.04 & 0.04 & 2 & - & - \\
\hline & & & & & 2 & 0.08 & 0.16 & 0.12 & 5 & - & - \\
\hline & & & & & 1 & 0.04 & 0.04 & 0.04 & 0.2 & - & - \\
\hline Apricot & 3 & ND & 0 & 0 & - & - & - & - & - & - & - \\
\hline Banana & 28 & ND & 0 & 0 & - & - & - & - & - & - & - \\
\hline \multirow[t]{2}{*}{ Cantaloupe } & \multirow[t]{2}{*}{17} & Diazinon & \multirow[t]{2}{*}{1} & \multirow[t]{2}{*}{5.9} & 1 & 0.05 & 0.05 & 0.05 & 0.2 & - & - \\
\hline & & Malathion & & & 1 & 0.04 & 0.04 & \begin{tabular}{|l|}
0.04 \\
\end{tabular} & - & - & - \\
\hline \multirow[t]{3}{*}{ Grape } & \multirow[t]{3}{*}{4} & Boscalid & \multirow[t]{3}{*}{1} & \multirow[t]{3}{*}{25} & 1 & 0.22 & 0.22 & 0.22 & 5 & - & - \\
\hline & & Clethodim $^{\star \star}$ & & & 1 & 0.02 & 0.02 & 0.02 & $0.5 \mathrm{EU}$ & - & - \\
\hline & & Pyraclostrobin & & & 1 & 0.04 & 0.04 & 0.04 & 2 & & \\
\hline \multirow[t]{2}{*}{ Guava } & \multirow[t]{2}{*}{13} & Cypermethrin & \multirow[t]{2}{*}{7} & \multirow[t]{2}{*}{54} & 4 & 0.06 & 0.13 & 0.09 & $0.05 \mathrm{EU}$ & 1 & 7.8 \\
\hline & & \begin{tabular}{|l|} 
Lambda- \\
Cyhalothrin
\end{tabular} & & & 4 & 0.02 & 0.07 & 0.05 & No MRL & - & - \\
\hline
\end{tabular}


Khorshed, Mona A.

Table (2): Continued

\begin{tabular}{|c|c|c|c|c|c|c|c|c|c|c|c|}
\hline Commodity & \begin{tabular}{|c|} 
Total no. \\
of \\
analyzed \\
samples \\
\end{tabular} & $\begin{array}{c}\text { The detected } \\
\text { pesticide }\end{array}$ & $\begin{array}{c}\text { Contamination } \\
\text { number }\end{array}$ & $\begin{array}{c}\text { Contamination } \\
\text { percentage }\end{array}$ & frequency & minimum & maximum & mean & $\begin{array}{c}\text { Maximum } \\
\text { Residue } \\
\text { Limits } \\
\text { (MRL) }\end{array}$ & $\begin{array}{c}\text { Violation } \\
\text { No. }\end{array}$ & $\begin{array}{c}\text { Violation } \\
\%\end{array}$ \\
\hline \multirow{8}{*}{ Strawberry } & 19 & Chlorpyrifos & 6 & 32 & 1 & 0.07 & 0.07 & 0.07 & 0.3 & 1 & 5 \\
\hline & & Cypermethrin & & & 1 & 0.13 & 0.13 & 0.13 & - & & \\
\hline & & Cyprodinil & & & 1 & 0.15 & 0.15 & 0.15 & 2 & & \\
\hline & & Ethion & & & 1 & 0.09 & 0.09 & 0.09 & $0.01 \mathrm{EU}$ & & \\
\hline & & Fenhexamid & & & 1 & 0.28 & 0.28 & 0.28 & 10 & & \\
\hline & & Fenpropathrin & & & 2 & 0.04 & 0.06 & 0.05 & - & & \\
\hline & & Iprodione & & & 1 & 0.11 & 0.11 & 0.11 & 10 & & \\
\hline & & Profenofos & & & 1 & 0.22 & 0.22 & 0.22 & - & & \\
\hline
\end{tabular}




\section{J. Plant Prot. and Path., Mansoura Univ., Vol. 3 (2), February, 2012}

Table (2): Continued

\begin{tabular}{|c|c|c|c|c|c|c|c|c|c|c|c|}
\hline Commodity & $\begin{array}{c}\text { Total no. } \\
\text { of } \\
\text { analyzed } \\
\text { samples }\end{array}$ & $\begin{array}{l}\text { The detected } \\
\text { pesticide }\end{array}$ & $\begin{array}{l}\text { Contam- } \\
\text { ination. } \\
\text { number }\end{array}$ & $\begin{array}{c}\text { Contam- } \\
\text { ination } \\
\text { Percent- } \\
\text { age }\end{array}$ & frequency & minimum & maximum & mean & \begin{tabular}{|c|} 
Maximum \\
Residue \\
Limits \\
(MRL)
\end{tabular} & $\begin{array}{c}\text { Violation } \\
\text { No. }\end{array}$ & $\begin{array}{c}\text { Violation } \\
\%\end{array}$ \\
\hline \multirow[t]{9}{*}{ Orange } & \multirow[t]{9}{*}{24} & Diazinon & 1 & \multirow[t]{9}{*}{11} & \multirow[t]{9}{*}{46} & 0.03 & 0.03 & 0.03 & $0.01 \mathrm{EU}$ & \multirow[t]{9}{*}{3} & \multirow[t]{9}{*}{13} \\
\hline & & Dimethoate & 1 & & & 0.11 & 0.11 & 0.11 & 5 & & \\
\hline & & Fenhexamid & 1 & & & 1.3 & 1.3 & 1.30 & $0.05 \mathrm{EU}$ & & \\
\hline & & Fenpropathrin & 1 & & & 0.05 & 0.05 & 0.05 & $2 \mathrm{EU}$ & & \\
\hline & & Imazalil & 3 & & & 0.39 & 3.5 & 2.10 & 5 & & \\
\hline & & $\begin{array}{l}\text { Lambda- } \\
\text { Cyhalothrin }\end{array}$ & 2 & & & 0.02 & 0.09 & 0.06 & $0.1 \mathrm{EU}$ & & \\
\hline & & Malathion & 5 & & & 0.03 & 0.14 & 0.05 & 7 & & \\
\hline & & Pirimiphos-methyl & 1 & & & 0.03 & 0.03 & 0.03 & 1 1EU & & \\
\hline & & Profenofos & 1 & & & 1.16 & 1.16 & 1.16 & $0.05 \mathrm{EU}$ & & \\
\hline \multirow[b]{2}{*}{ Peach } & \multirow[b]{2}{*}{7} & Carbendazim & 1 & \multirow[t]{2}{*}{1} & \multirow[t]{2}{*}{14} & 0.01 & 0.01 & 0.01 & 2 & \multirow[t]{2}{*}{0} & \multirow[t]{2}{*}{0} \\
\hline & & $\begin{array}{l}\text { Lambda- } \\
\text { Cyhalothrin }\end{array}$ & 1 & & & 0.02 & 0.02 & 0.02 & $0.2 \mathrm{EU}$ & & \\
\hline \multirow[b]{2}{*}{ Pomegranates } & \multirow[b]{2}{*}{1} & Ethion & 1 & \multirow[t]{2}{*}{1} & \multirow[t]{2}{*}{100} & 0.04 & 0.04 & 0.04 & - & & \\
\hline & & $\begin{array}{l}\text { Lambda- } \\
\text { Cyhalothrin }\end{array}$ & 1 & & & 0.06 & 0.06 & 0.06 & - & & \\
\hline Total no. of fruits & 120 & & & 30 & 25 & & & & & 5 & 4.2 \\
\hline
\end{tabular}


Khorshed, Mona A.

Table (2): Continued

\begin{tabular}{|c|c|c|c|c|c|c|c|c|c|c|c|}
\hline Commodity & $\begin{array}{c}\text { Total no. } \\
\text { of } \\
\text { analyzed } \\
\text { samples }\end{array}$ & $\begin{array}{l}\text { The detected } \\
\text { pesticide }\end{array}$ & $\begin{array}{l}\text { Contamina- } \\
\text { tion no. }\end{array}$ & \begin{tabular}{|c}
$\begin{array}{c}\text { Contamina- } \\
\text { tion } \\
\text { percentage }\end{array}$ \\
\end{tabular} & frequency & minimum & maximum & mean & $\begin{array}{c}\text { Maximum } \\
\text { Residue } \\
\text { Limits } \\
\text { (MRL) }\end{array}$ & $\begin{array}{c}\text { Violation } \\
\text { No. }\end{array}$ & $\begin{array}{c}\text { Violation } \\
\%\end{array}$ \\
\hline \multirow{2}{*}{$\begin{array}{l}\text { Vegetables: } \\
\text { Cabbage }\end{array}$} & \multirow[t]{2}{*}{23} & Chlorpyrifos & \multirow[t]{2}{*}{2} & \multirow[t]{2}{*}{9} & 1 & 0.03 & 0.03 & 0.03 & 1 & - & - \\
\hline & & Diazinon & & & 1 & 0.19 & 0.19 & 0.19 & 0.5 & & \\
\hline Carrot & 22 & Profenofos & 1 & 5 & 1 & 0.25 & 0.25 & 0.25 & $0.05 \mathrm{EU}$ & 1 & 5 \\
\hline Cauliflower & 22 & Fenhexamid & 1 & 5 & 1 & 0.24 & 0.24 & 0.24 & $0,05 \mathrm{EU}$ & 1 & 5 \\
\hline \multirow[t]{5}{*}{ Cucumber } & \multirow[t]{5}{*}{22} & Cypermethrin & \multirow[t]{5}{*}{7} & \multirow[t]{5}{*}{32} & 2 & 0.05 & 0.27 & 0.16 & 0.2 & \multirow[t]{5}{*}{2} & \multirow[t]{5}{*}{9} \\
\hline & & Ethion & & & 2 & 0.03 & 0.12 & 0.08 & $0.01 \mathrm{EU}$ & & \\
\hline & & Fenhexamid & & & 1 & 1.6 & 1.6 & 1.60 & 1 & & \\
\hline & & $\begin{array}{l}\text { Lambda- } \\
\text { Cyhalothrin }\end{array}$ & & & 2 & 0.02 & 0.02 & 0.02 & $0.1 \mathrm{EU}$ & & \\
\hline & & Procymidone & & & 1 & 0.13 & 0.13 & 0.13 & 2 & & \\
\hline \multirow[t]{3}{*}{ Egg plant } & \multirow[t]{3}{*}{37} & Ethion & \multirow[t]{3}{*}{4} & \multirow[t]{3}{*}{11} & 3 & 0.03 & 0.56 & 0.21 & $0.01 \mathrm{EU}$ & \multirow[t]{3}{*}{1} & \multirow[t]{3}{*}{3} \\
\hline & & Fenhexamid & & & 1 & 1.4 & 1.4 & 1.40 & 2 & & \\
\hline & & Fenpropathrin & & & 1 & 0.16 & 0.16 & 0.16 & 0.2 & & \\
\hline \multirow[t]{3}{*}{ Green beans } & \multirow[t]{3}{*}{20} & Fenhexamid & \multirow[t]{3}{*}{3} & \multirow[t]{3}{*}{15} & 1 & 4.1 & 4.1 & 4.10 & $2 \mathrm{EU}$ & \multirow[t]{3}{*}{1} & \multirow[t]{3}{*}{5} \\
\hline & & $\begin{array}{l}\text { Lambda- } \\
\text { Cyhalothrin }\end{array}$ & & & 1 & 0.02 & 0.02 & 0.02 & $0.2 E U$ & & \\
\hline & & Procymidone & & & 1 & 0.06 & 0.06 & 0.06 & 1EU & & \\
\hline
\end{tabular}




\section{J. Plant Prot. and Path., Mansoura Univ., Vol. 3 (2), February, 2012}

Table (2): Continued

\begin{tabular}{|c|c|c|c|c|c|c|c|c|c|c|c|}
\hline Commodity & $\begin{array}{c}\text { Total no. } \\
\text { of } \\
\text { analyzed } \\
\text { samples }\end{array}$ & $\begin{array}{l}\text { The detected } \\
\text { pesticide }\end{array}$ & $\begin{array}{c}\text { Contamination. } \\
\text { number }\end{array}$ & $\begin{array}{c}\text { Contamination } \\
\text { percentage }\end{array}$ & frequency & minimum & maximum & mean & \begin{tabular}{|c|} 
Maximum \\
Residue \\
Limits \\
(MRL)
\end{tabular} & $\begin{array}{c}\text { Violation } \\
\text { No. }\end{array}$ & $\underset{\%}{\text { Violation }}$ \\
\hline \multirow[t]{5}{*}{ Green Peas } & \multirow[t]{5}{*}{25} & Chlorpyrifos & \multirow[t]{5}{*}{5} & \multirow[t]{5}{*}{20} & 1 & 0.03 & 0.03 & 0.03 & $0.05 \mathrm{EU}$ & \multirow[t]{5}{*}{1} & \multirow[t]{5}{*}{4} \\
\hline & & Ethion & & & 1 & 0.05 & 0.05 & 0.05 & $0.01 \mathrm{EU}$ & & \\
\hline & & Fenhexamid & & & 1 & 0.83 & 0.83 & 0.83 & $0.05 \mathrm{EU}$ & & \\
\hline & & $\begin{array}{l}\text { Lambda- } \\
\text { Cyhalothrin }\end{array}$ & & & 1 & 0.11 & 0.11 & 0.11 & $0.2 \mathrm{EU}$ & & \\
\hline & & Profenofos & & & 1 & 0.1 & 0.1 & 0.10 & $0.05 \mathrm{EU}$ & & \\
\hline Lettuce & 20 & $\begin{array}{l}\text { no Pesticide } \\
\text { detected }\end{array}$ & - & - & - & - & - & - & - & - & - \\
\hline Molokia & 10 & Malathion & 1 & 10 & 1 & 0.03 & 0.03 & 0.03 & 5.00 & - & - \\
\hline \multirow{3}{*}{ Pepper } & \multirow{3}{*}{25} & Dimethoate & \multirow[t]{3}{*}{4} & \multirow[t]{3}{*}{16} & 1 & 0.12 & 0.12 & 0.12 & 1 & \multirow[t]{3}{*}{2} & \multirow[t]{3}{*}{8} \\
\hline & & Fenhexamid & & & 1 & 3.2 & 3.2 & 3.20 & 2 & & \\
\hline & & Profenofos & & & 2 & 0.38 & 1.34 & 0.86 & 0.5 & & \\
\hline Potatoes & 24 & Fenhexamid & 2 & 8 & 2 & 0.05 & 1.2 & 0.63 & $0.05 \mathrm{EU}$ & 1 & 4 \\
\hline \multirow[t]{2}{*}{ Squash } & \multirow[t]{2}{*}{24} & Fenhexamid & \multirow[t]{2}{*}{2} & \multirow[t]{2}{*}{8} & 1 & 0.26 & 0.26 & 0.26 & 1 & - & - \\
\hline & & Metalaxyl & & & 1 & 0.08 & 0.08 & 0.08 & 0.2 & - & - \\
\hline
\end{tabular}


Khorshed, Mona A.

Table (2): Continued

\begin{tabular}{|c|c|c|c|c|c|c|c|c|c|c|c|}
\hline Commodity & \begin{tabular}{|c|} 
Total no. \\
of \\
analyzed \\
samples
\end{tabular} & $\begin{array}{l}\text { The detected } \\
\text { pesticide }\end{array}$ & $\begin{array}{c}\text { Contamination. } \\
\text { no. }\end{array}$ & $\begin{array}{c}\text { Contamination } \\
\text { percentage }\end{array}$ & frequency & minimum & maximum & mean & $\begin{array}{c}\text { Maximum } \\
\text { Residue } \\
\text { Limits } \\
\text { (MRL) }\end{array}$ & $\begin{array}{c}\text { Violation } \\
\text { No. }\end{array}$ & $\underset{\%}{\text { Violation }}$ \\
\hline \multirow[t]{6}{*}{ Tomato } & 25 & Chlorfenapyr & 5 & 20 & 1 & 0.03 & 0.03 & 0.03 & $0.05 \mathrm{EU}$ & 1 & 4 \\
\hline & & Cypermethrin & & & 1 & 0.08 & 0.08 & 0.08 & 0.5 & & \\
\hline & & Ethion & & & 1 & 0.05 & 0.05 & 0.05 & $0.01 \mathrm{EU}$ & & \\
\hline & & Fenhexamid & & & 1 & 0.4 & 0.4 & 0.40 & 2 & & \\
\hline & & $\begin{array}{l}\text { Lambda- } \\
\text { Cyhalothrin }\end{array}$ & & & 1 & 0.03 & 0.03 & 0.03 & $0.1 \mathrm{EU}$ & & \\
\hline & & Profenofos & & & 1 & 0.44 & 0.44 & 0.44 & 2 & & \\
\hline Total & 299 & & 37 & 12.4 & & & & & & 11 & 2.7 \\
\hline
\end{tabular}




\section{J. Plant Prot. and Path., Mansoura Univ., Vol. 3 (2), February, 2012}

Table (2): Continued

\begin{tabular}{|c|c|c|c|c|c|c|c|c|c|c|c|}
\hline Commodity & $\begin{array}{c}\text { Total no. } \\
\text { of } \\
\text { analyzed } \\
\text { samples }\end{array}$ & $\begin{array}{c}\text { The detected } \\
\text { pesticide }\end{array}$ & $\begin{array}{l}\text { Contamina- } \\
\text { tion. number }\end{array}$ & $\begin{array}{l}\text { Contamina- } \\
\text { tion } \\
\text { percentage }\end{array}$ & frequency & minimum & maximum & mean & $\begin{array}{c}\text { Maximum } \\
\text { Residue } \\
\text { Limits } \\
\text { (MRL) }\end{array}$ & $\begin{array}{c}\text { Violation } \\
\text { No. }\end{array}$ & $\begin{array}{c}\text { Violation } \\
\%\end{array}$ \\
\hline \multicolumn{12}{|l|}{ Leafy } \\
\hline $\begin{array}{l}\text { vegetables: } \\
\text { Water Cress }\end{array}$ & 23 & Profenofos & 3 & 13 & 3 & 0.08 & 2.8 & 1.07 & $0.05 E U$ & 3 & 13 \\
\hline Spinach & 24 & Malathion & 1 & 4 & 1 & 0.03 & 0.03 & 0.03 & 3 & - & - \\
\hline \begin{tabular}{|l|} 
Egyptian \\
Mallow
\end{tabular} & 15 & Malathion & 1 & 7 & 1 & 0.1 & 0.1 & 0.10 & no MRL & - & - \\
\hline Grape leaf & 7 & Flusilazole & 1 & 14 & 1 & 0.2 & 0.2 & 0.20 & - & - & - \\
\hline Green Celery & 2 & $\begin{array}{l}\text { no Pesticide } \\
\text { detected }\end{array}$ & - & - & - & - & - & - & - & - & - \\
\hline \multirow[b]{2}{*}{$\begin{array}{l}\text { Green } \\
\text { Coriander }\end{array}$} & \multirow[b]{2}{*}{17} & Chlorpyrifos & 4 & 24 & 1 & 1.96 & 1.96 & 1.96 & $0.05 \mathrm{EU}$ & 4 & 24 \\
\hline & & Profenofos & - & - & 3 & 0.04 & 1.56 & 0.55 & $0.05 \mathrm{EU}$ & & \\
\hline \multirow[t]{3}{*}{ Green Parsley } & \multirow[t]{3}{*}{23} & Chlorpyrifos & 5 & 22 & 1 & 0.08 & 0.08 & 0.08 & $0.05 \mathrm{EU}$ & 1 & 4 \\
\hline & & Malathion & & & 2 & 0.05 & 0.07 & 0.06 & $0.02 \mathrm{EU}$ & & \\
\hline & & Profenofos & & & 4 & 0.09 & 0.48 & 0.33 & $0.05 \mathrm{EU}$ & & \\
\hline Total & 111 & & 15 & 13.5 & & & & & & 8 & 7.2 \\
\hline Total samples & 530 & & 82 & 15.5 & & & & & & 24 & 4.5 \\
\hline
\end{tabular}


Khorshed, Mona A.

Table (4): Estimated dietary intake for chronic risk for those 13 pesticides, which were the highest frequently detected in the samples.

\begin{tabular}{|c|c|c|c|c|c|c|c|}
\hline Compound & Commodity & $\begin{array}{l}\text { Mean } \\
\text { conc. } \\
\text { mg/kg }\end{array}$ & $\begin{array}{c}\text { food } \\
\text { consumption } \\
\text { g/day }\end{array}$ & $\begin{array}{c}\text { Estimated } \\
\text { Acceptable daily } \\
\text { intakes (EADI) } \\
\mathrm{mg} / \mathbf{k g}\end{array}$ & $\begin{array}{c}\text { Estimated } \\
\text { Acceptable daily } \\
\text { intakes (EADI) } \\
\text { mg/kg.bw /day }\end{array}$ & $\begin{array}{c}\text { Acceptable Daily } \\
\text { Intakes (ADI) } \\
\text { mg/kg.bw /day }\end{array}$ & $\begin{array}{c}\text { Highest } \\
\text { calculated } \\
\text { EADI in \% of } \\
\text { the ADI }\end{array}$ \\
\hline \multirow[t]{9}{*}{ Profenofos } & Orange & 1.16 & 38 & 0.04408 & 0.0007346667 & 0.03 & $2.44889 \%$ \\
\hline & Carrot & 0.25 & 8.1 & 0.002025 & 0.0000337500 & 0.03 & $0.11250 \%$ \\
\hline & Green Peas & 0.10 & 6 & 0.0006 & 0.0000100000 & 0.03 & $0.03333 \%$ \\
\hline & Pepper & 0.86 & 13 & 0.01118 & 0.0001863333 & 0.03 & $0.62111 \%$ \\
\hline & Strawberry & 0.22 & 2 & 0.00044 & 0.0000073333 & 0.03 & $0.02444 \%$ \\
\hline & Tomato & 0.44 & 118 & 0.05192 & 0.0008653333 & 0.03 & $2.88444 \%$ \\
\hline & Water Cress & 1.07 & 3.3 & 0.003531 & 0.0000588500 & 0.03 & $0.19617 \%$ \\
\hline & Green Coriander & 0.55 & 1.5 & 0.00083 & 0.0000138333 & 0.03 & $0.04611 \%$ \\
\hline & Green Parsley & 0.33 & 1.5 & 0.00049875 & 0.0000083125 & 0.03 & $0.02771 \%$ \\
\hline \multirow[t]{5}{*}{ Chlorpyrifos } & Cabbage & 0.03 & 8.3 & 0.000249 & 0.0000041500 & 0.01 & $0.04150 \%$ \\
\hline & Green Peas & 0.03 & 6 & 0.00018 & 0.0000030000 & 0.01 & $0.03000 \%$ \\
\hline & Strawberry & 0.07 & 2 & 0.00014 & 0.0000023333 & 0.01 & $0.02333 \%$ \\
\hline & Green Coriander & 1.96 & 1.5 & 0.00294 & 0.0000490000 & 0.01 & $0.49000 \%$ \\
\hline & Green Parsley & 0.08 & 1.5 & 0.00012 & 0.0000020000 & 0.01 & $0.02000 \%$ \\
\hline \multirow[t]{5}{*}{ Cypermethrin } & Apple & 0.04 & 18.5 & 0.00074 & 0.0000123333 & 0.02 & $0.06167 \%$ \\
\hline & Guava & 0.09 & 0.2 & 0.000018 & 0.0000003000 & 0.02 & $0.00150 \%$ \\
\hline & Cucumber & 0.16 & 22.6 & 0.003616 & 0.0000602667 & 0.02 & $0.30133 \%$ \\
\hline & Strawberry & 0.13 & 2 & 0.00026 & 0.0000043333 & 0.02 & $0.02167 \%$ \\
\hline & Tomato & 0.08 & 118 & 0.00944 & 0.0001573333 & 0.02 & $0.78667 \%$ \\
\hline \multirow[t]{6}{*}{ Ethion } & Promegranate & 0.04 & 0.2 & 0.000008 & 0.0000001333 & 0.002 & $0.00667 \%$ \\
\hline & Cucumber & 0.08 & 22.6 & 0.001695 & 0.0000282500 & 0.002 & $1.41250 \%$ \\
\hline & Egg plant & 0.21 & 12.3 & 0.002583 & 0.0000430500 & 0.002 & $2.15250 \%$ \\
\hline & Green Peas & 0.05 & 6 & 0.0003 & 0.0000050000 & 0.002 & $0.25000 \%$ \\
\hline & Strawberry & 0.09 & 2 & 0.00018 & 0.0000030000 & 0.002 & $0.15000 \%$ \\
\hline & Tomato & 0.05 & 118 & 0.0059 & 0.0000983333 & 0.002 & $4.91667 \%$ \\
\hline \multirow[t]{6}{*}{ Malathion } & Cantaloupe & 0.04 & 22.6 & 0.000904 & 0.0000150667 & 0.3 & $0.00502 \%$ \\
\hline & Orange & 0.05 & 38 & 0.002052 & 0.0000342000 & 0.3 & $0.01140 \%$ \\
\hline & Molokia & 0.03 & 1.1 & 0.000033 & 0.0000005500 & 0.3 & $0.00018 \%$ \\
\hline & Spinach & 0.03 & 1.1 & 0.000033 & 0.0000005500 & 0.3 & $0.00018 \%$ \\
\hline & Egyptian Mallow & 0.10 & 1.1 & 0.00011 & 0.0000018333 & 0.3 & $0.00061 \%$ \\
\hline & Green Parsley & 0.06 & 1.5 & 0.00009 & 0.0000015000 & 0.3 & $0.00050 \%$ \\
\hline
\end{tabular}


J. Plant Prot. and Path., Mansoura Univ., Vol. 3 (2), February, 2012

\begin{tabular}{|c|c|c|c|c|c|c|c|}
\hline Compound & Commodity & $\begin{array}{l}\text { Mean } \\
\text { conc. } \\
\mathrm{mg} / \mathrm{kg}\end{array}$ & $\begin{array}{c}\text { food consumption } \\
\text { g/day }\end{array}$ & $\begin{array}{c}\text { Estimated } \\
\text { Acceptable daily } \\
\text { intakes (EADI) } \\
\text { mg/kg }\end{array}$ & $\begin{array}{c}\text { Estimated } \\
\text { Acceptable daily } \\
\text { intakes (EADI) } \\
\text { mg/kg.bw /day }\end{array}$ & $\begin{array}{l}\text { Acceptable Daily } \\
\text { Intakes (ADI) } \\
\text { mg/kg.bw /day }\end{array}$ & $\begin{array}{c}\text { Highest } \\
\text { calculated } \\
\text { EADI in \% of } \\
\text { the ADI }\end{array}$ \\
\hline \multirow[t]{11}{*}{ Fenhexamid } & Orange & 1.30 & 38 & 0.0494 & 0.0008233333 & 0.2 & $0.41167 \%$ \\
\hline & Cauliflower & 0.24 & 1.2 & 0.000288 & 0.0000048000 & 0.2 & $0.00240 \%$ \\
\hline & Cucumber & 1.60 & 22.6 & 0.03616 & 0.0006026667 & 0.2 & $0.30133 \%$ \\
\hline & Egg plant & 1.40 & 12.3 & 0.01722 & 0.0002870000 & 0.2 & $0.14350 \%$ \\
\hline & Green beans & 4.10 & 4.5 & 0.01845 & 0.0003075000 & 0.2 & $0.15375 \%$ \\
\hline & Green Peas & 0.83 & 6 & 0.00498 & 0.0000830000 & 0.2 & $0.04150 \%$ \\
\hline & Pepper & 3.20 & 13 & 0.0416 & 0.0006933333 & 0.2 & $0.34667 \%$ \\
\hline & Potatoes & 0.63 & 61.2 & 0.03825 & 0.0006375000 & 0.2 & $0.31875 \%$ \\
\hline & Squash & 0.26 & 14.4 & 0.003744 & 0.0000624000 & 0.2 & $0.03120 \%$ \\
\hline & Strawberry & 0.28 & 2 & 0.00056 & 0.0000093333 & 0.2 & $0.00467 \%$ \\
\hline & Tomato & 0.40 & 118 & 0.0472 & 0.0007866667 & 0.2 & $0.39333 \%$ \\
\hline \multirow[t]{9}{*}{ Lambda-Cyhalothrin } & Apple & 0.04 & 18.5 & 0.00074 & 0.0000123333 & 0.02 & $0.06167 \%$ \\
\hline & Guava & 0.05 & 0.2 & 0.0000095 & 0.0000001583 & 0.02 & $0.00079 \%$ \\
\hline & Orange & 0.06 & 38 & 0.00209 & 0.0000348333 & 0.02 & $0.17417 \%$ \\
\hline & Peach & 0.02 & 3.3 & 0.000066 & 0.0000011000 & 0.02 & $0.00550 \%$ \\
\hline & Promegranate & 0.06 & 0.2 & 0.000012 & 0.0000002000 & 0.02 & $0.00100 \%$ \\
\hline & Cucumber & 0.02 & 22.6 & 0.000452 & 0.0000075333 & 0.02 & $0.03767 \%$ \\
\hline & Green beans & 0.02 & 4.5 & 0.00009 & 0.0000015000 & 0.02 & $0.00750 \%$ \\
\hline & Green Peas & 0.11 & 6 & 0.00066 & 0.0000110000 & 0.02 & $0.05500 \%$ \\
\hline & Tomato & 0.03 & 118 & 0.00354 & 0.0000590000 & 0.02 & $0.29500 \%$ \\
\hline \multirow[t]{4}{*}{ Fenpropathrin } & Apple & 0.12 & 18.5 & 0.00222 & 0.0000370000 & 0.03 & $0.12333 \%$ \\
\hline & Orange & 0.05 & 38 & 0.0019 & 0.0000316667 & 0.03 & $0.10556 \%$ \\
\hline & Egg plant & 0.16 & 12.3 & 0.001968 & 0.0000328000 & 0.03 & $0.10933 \%$ \\
\hline & Strawberry & 0.05 & 2 & 0.0001 & 0.0000016667 & 0.03 & $0.00556 \%$ \\
\hline \multirow[t]{3}{*}{ Diazinon } & Cantaloupe & 0.05 & 22.6 & 0.00113 & 0.0000188333 & 0.005 & $0.37667 \%$ \\
\hline & Orange & 0.03 & 38 & 0.00114 & 0.0000190000 & 0.005 & $0.38000 \%$ \\
\hline & Cabbage & 0.19 & 8.3 & 0.001577 & 0.0000262833 & 0.005 & $0.52567 \%$ \\
\hline Imazalil & Orange & 2.10 & 38 & 0.079673333 & 0.0013278889 & 0.03 & $4.42630 \%$ \\
\hline \multirow[t]{2}{*}{ Carbendazim } & Apple & 0.09 & 18.5 & 0.001665 & 0.0000277500 & 0.03 & $0.09250 \%$ \\
\hline & Peach & 0.01 & 3.3 & 0.000033 & 0.0000005500 & 0.03 & $0.00183 \%$ \\
\hline \multirow[t]{2}{*}{ Dimethoate } & Orange & 0.11 & 38 & 0.00418 & 0.0000696667 & 0.002 & $3.48333 \%$ \\
\hline & Pepper & 0.12 & 13 & 0.00156 & 0.0000260000 & 0.002 & $1.30000 \%$ \\
\hline \multirow[t]{2}{*}{ Procymidone } & Cucumber & 0.13 & 22.6 & 0.002938 & 0.0000489667 & 0.1 & $0.04897 \%$ \\
\hline & Green beans & 0.06 & 4.5 & 0.00027 & 0.0000045000 & 0.1 & $0.00450 \%$ \\
\hline
\end{tabular}


Khorshed, Mona A. 